\title{
Financial Ratios and Probability of Default by Using the KMV-Merton Method in the Non-Financial Sector Listed on the Indonesia Stock Exchange
}

\author{
D. Malasaria ${ }^{a}$ M. Adam ${ }^{\mathrm{b}}$, Yuliani $^{\mathrm{c}}$, A. Hanafi $^{\mathrm{d}}$ \\ Sriwijaya University, Palembang, Indonesia \\ a https://orcid.org/0000-0003-3461-9701; b https://orcid.org/0000-0002-3260-3266; \\ c https://orcid.org/0000-0003-3488-7941; ${ }^{\mathrm{d}}$ https://orcid.org/0000-0003-2966-3943
}

\begin{abstract}
This study aims to analyze the predictions of the default probability in the non-financial sector of the Indonesia Stock Exchange and the mutual influence between financial ratios. The KMV-Merton method was used for the calculations. The study was conducted on the example of data from 18 companies listed on the Indonesia Stock Exchange. The scientific materials and documentation were analyzed with the help of the EViews. The authors made the following conclusions: Return on Equity (ROE) has no effect on the probability of default; Current Ratio (CR) has no effect on the probability of default; Debt to Equity Ratio (DER) has a positive effect on the probability of default; Total Assets Turnover (TAT) has a negative effect on the probability of default.
\end{abstract}

Keywords: probability of default; KMV-Merton method; financial ratio; Indonesia Stock Exchange

For citation: Malasari D., Adam M., Yuliani, Hanafi A. Financial ratios and probability of default from using the KMV-Merton Method in the non-financial sector listed on the Indonesia stock exchange. Finance: Theory and Practice. 2020;24(1):6-13. DOI: 10.26794/2587-5671-2020-24-1-6-13

ОРИГИНАЛЬНАЯ СТАТЬЯ

\section{Финансовые показатели и вероятность} дефолта, вычисленные по методу КМВ-Мертона в нефинансовом секторе на фондовой бирже Индонезии

\author{
Д. Маласари ${ }^{a}$ М. Адам ${ }^{\mathrm{b}}$ Юлиани, А. Ханафи ${ }^{\mathrm{d}}$, \\ Университет Шривиджая, Палембанг, Индонезия

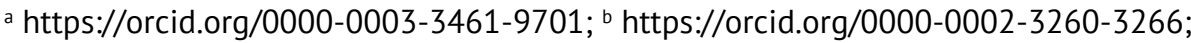 \\ c https://orcid.org/0000-0003-3488-7941; ${ }^{d}$ https://orcid.org/0000-0003-2966-3943
}

\section{АННОТАЦИЯ}

Цель статьи - анализ прогнозов вероятности дефолта в нефинансовом секторе фондовой биржи Индонезии и взаимовлияния при этом финансовых показателей. При вычислениях использован метод КМВ-Мертона. Исследование проводилось на примере данных 18 компаний, котирующихся на фондовой бирже Индонезии. Проанализированы научные материалы и документация с использованием программы Eviews. В результате авторы сделали следующие выводы: рентабельность капитала (ROE) не влияет на вероятность дефолта; коэффициент текущей ликвидности (CR) не влияет на вероятность дефолта; соотношение долга к капиталу (DER) положительно влияет на вероятность дефолта; общий оборот активов (ТАТ) отрицательно влияет на вероятность дефолта.

Ключевые слова: вероятность дефолта; метод КМВ-Мертона; финансовый коэффициент; фондовая биржа Индонезии

Для цитирования: Malasari D., Adam M., Yuliani, Hanafi A. Financial ratios and probability of default from using the KMV-Merton Method in the non-financial sector listed on the Indonesia stock exchange. Финансы: теория и практика. 2020;24(1):6-13. DOI: 10.26794/2587-5671-2020-24-1-6-13

(c) Malasari D., Adam M., Yuliani, Hanafi A., 2020 


\section{INTRODUCTION}

The default happened in PT Mobile- 8 Telecom Tbk in 2009 to 2010. This company failed to pay the 12th bond interest. In March 2009, IDX also suspended FREN stock and bonds because it could not pay the bond interest of Rp 675 billion due to the company's default; the rating agency PEFINDO downgraded the company's bonds from "CC" to "D". Defaults also occurred in PT Sunprima Nusantara Financing or SNP Finance. Previously, in December 2015 to November 2017, SNP Finance had an idA rating; then, in March 2018, the rating became idA. Finally, in May 2018, PEFINDO downgraded the SNF Finance rating to idCCC, then in the same month PEFINDO lowered its rating to idSD / selective default. In addition to SNP Finance, cases of default on bonds or interest that occurred in 2018 were also experienced by PT Express Transindo Utama and PT Tiga Pilar Sejahtera Food.

The default phenomenon experienced by many companies increasingly emphasizes the importance of measuring credit risk. The purpose of measuring credit risk is to estimate the default probability in a company when the obligation is due. There are two credit risk models, namely structural models and reduced models. The assumption of the structural model is that the company goes bankrupt when the value of the company's assets falls below the critical limit when due. The formation of structural models begins with the seminar paper by Black and Scholes in 1973. In 1974, Merton developed the model by creating a risk bankruptcy model for companies using Black-Scholes modification (Merton, 1974) [1]; so, the structural model is known as the Black-Scholes-Merton (BSM) method.

Olddrich Vasicek and Stephen Kealhofer modified and developed the Merton model to the VK model (Crosbie and Bohn, 2003) [2]. KMV (financial consulting company in the United States) then developed the VK model which finally became the KMV-Merton model. The advantage of the KMV-Merton model is that it can predict failure in quantitative form of financial ratios (Rudiyanto, 2012) [3]. With financial ratios, it can be seen whether the company has achieved a good level of efficiency in achieving results and making optimal use of funds. By looking at the relationship between financial ratios and the possible risk of default, the interested parties can decide on the steps to see possible risks of default. In assessing bonds, rating agents are influenced by several factors, one of which is financial ratios.

Several studies on the probability of default, the KMVMerton model and credit risk have been conducted by Hadad (2004), Fernandes (2005), Manurung (2007), Petra (2011), Asdriargo et al (2012), Konstituanto (2012), Muharam (2012), Saleh and Sudiyatno (2013), Agus et al (2014), Ayomi and Hermanto (2014), Pribadi et al (2014), Wendy (2015) and Wibowo (2017) [4-16]. Corporate credit risk in the agriculture sector using the KMV-Merton method shows that the KMV-Merton model can be used fairly well and is an early signal of credit risk and credit problems faced by public sector companies in Indonesia (Hadad, 2004) [4]. Current Ratio, Debt Service Ratio, Interest Cost and Productivity Ratio affect credit risk (Fernandes, 2005) [5]. Banks have a higher probability of default than other industry companies (Manurung, 2007) do [6]. Petra (2011), Asdriargo et al (2012), Pribadi et al (2014) $[7,8,14]$ stated that the KMV-Merton model can be used in credit risk.

Several researchers, including Benos and Papanastasopoulos (2005) [17], Widarjo and Setiawan (2009) [18], Saleh and Sudiyatno (2013) [11], studied the effect of profitability on the probability of default and stated that profitability affects the probability of default. The results of research by Almilia and Kristijadi (2003) [19], Mulyaningrum (2008) [20], Konstituanto (2012) [9], and Agus et al (2014) [12] show that profitability has no effect on the probability of default. Research on the effect of liquidity on the probability of default by Almilia and Kristijadi (2003) [19], Fernandes (2005) [5], Pranowo (2010) [21], Konstituanto (2012) [9] showed that liquidity has an effect on the probability of default. The results of the study by Widarjo and Setiawan (2009) [18] and Saleh and Sudiyatno (2013) [11] did not show the effect of liquidity on the probability of default.

Research on the effect of leverage on the probability of default was conducted by Almilia and Kristijadi (2003) [19], Saleh and Sudiyatno (2013) [11]. The results of the study show that leverage affects the probability of default. The research results are inversely proportional to the results of the study by Widarjo and Setiawan (2009) [18], which states that leverage does not affect the probability of default.

Research on the effect of activity on the probability of default by Konstituanto (2012) [9], Jiming \& Weiwei (2011) [22] states that activity influences the probability of default. Different results were received by Saleh and Sudiyatno (2013) [11] showing that the activity had no effect on the probability of default.

The difference in the results of the previous research is the basis of the current research. This research was conducted to reexamine the influence of financial ratios in predicting the probability of default in companies listed on the Indonesia Stock Exchange.

\section{THEORETICAL FRAMEWORK Signaling Theory}

The signaling theory, according to Brigham and Houston (2001) [23], is the company's action in giving signals to investors about how the management views the company. The signaling theory explains how the 
signals of success or failure of the management (agent) are conveyed to the owner (principal). Encouragement in giving signals is due to asymmetric information between the company (management) and outsiders, where investors know that the company's internal information is relatively less and slower than that of the management. Prospective investors, who will invest in the company's bonds, need information about the condition of the bonds.

The company's management is expected to give signals in the form of information about the condition or quality of the bonds, whether they have the potential to default or not. The signaling theory in this study explains that the company's management is the party that gives signals in the form of corporate financial statements and non-financial information to rating agencies. This bond rating agency carries out the rating process so that it can issue bond ratings for these bond issuing companies. Bond ratings give a signal about the probability of the company's debt service failure.

Spence (1973) [24] argues that by giving a signal, the sender (owner of information) tries to provide relevant pieces of information that can be utilized by the recipient. The recipient will then adjust his behavior according to his understanding of the signal. The signaling theory explains why companies strive to provide financial statements to external parties. Signals given by the managers aim to reduce information asymmetry between the company's management and external parties.

\section{The KMV-Merton Model}

Based on the Black-Scholes option theory, Merton (1974) [1] creates a structural valuation model, or Merton model. It was based on the assumption that the company's liabilities (equity and debt) are contingent claims for the company's purchases (Benos and Papanastasopoulos, 2007) [17]. According to Merton, corporate failure can be predicted with the help of the indicators of equity, total assets and corporate debt. According to Agus (2014) [12], the advantages of the KMV-Merton model compared to other models are applicable to public companies ${ }^{1}$.

$$
\mathrm{PD}=1-\mathrm{N}(\mathrm{DD})
$$

\section{Profitability Ratio (Return On Equity)}

The company's ability to earn profits both in relation to total assets, sales and own capital is the understanding

\footnotetext{
${ }^{1}$ URL: http://www.pefindo.com/index.php/pageman/page/ repdesc?t=desc \&id=4087http://www.pefindo.com/index. $\mathrm{php} /$ pageman/page/repdesc? $\mathrm{t}=$ desc $\& \mathrm{id}=6122$ (accessed on 10.01.2020).
}

of profitability (Sartono, 2001) [25]. Return On Equity (ROE) is the ratio to measure net income after tax with own capital.

$$
\text { Return on Equity }(\mathrm{ROE})=\frac{\text { Net Income }}{\text { Equity }} \text {. }
$$

\section{Liquidity Ratio (Current Ratio)}

Current Ratio (CR) is the extent to which assets can be used smoothly to cover short-term liabilities or current debt (Kasmir, 2009) [26]. There is no absolute requirement regarding the level of Current Ratio, because it usually depends on the type of business the company is running, however a CR Level of 2 is considered good (Lukman, 2004) [27].

$$
\text { Current Ratio }(\mathrm{CR})=\frac{\text { Current Asset }}{\text { Current Debt }} \text {. }
$$

\section{Leverage Ratio (Debt to Equity Ratio)}

Leverage ratio is a ratio used to measure the extent to which a company's assets are financed by debt. The higher the Debt to Equity Ratio (DER) is, the less profitable it is because the higher is the risk or failure that may occur in the company (Kasmir, 2009) [26].

$$
\text { Debt to Equity Ratio }(\mathrm{DER})=\frac{\text { Total Debt }}{\text { Equity }} \text {. }
$$

\section{Activity Ratio (Total Assets Turnover)}

According to Hanafi and Halim (2009) [28], Total Assets Turnover (TAT) is a ratio to calculate the effectiveness of the use of total assets, so that a high ratio shows good management, otherwise a low ratio must make management evaluate its strategy, marketing and capital expenditure (investment).

$$
\text { Total Assets Turnover }(\mathrm{TAT})=\frac{\text { Sales }}{\text { Total assets }} \text {. }
$$

\section{METHODOLOGY}

The data used is secondary data, which is a combination of time series data for the period of 2013-2016 with cross data (cross section) for 18 companies namely, Adhi Karya, Tiga Pilar Sejahtera Food, Agung Podomoroland, Global Mediacom, Bumi Serpong Damai, Duta Anggada Realty, Intiland Development, Fast Food Indonesia, Indofood Sukses Makmur, Kimia Farma, Lautan Luas, Mitra Adiperkasa, Modernland Realty, Pembangunan Jaya Ancol, Nippon Indosari Corpindo, Summarecon Agung, Surya Semesta Internusa, and Teleko- 
monikasi Indonesia ${ }^{2}$. This research was conducted on the non-financial sector companies listed on the Indonesia Stock Exchange for the period of 2013-2016 and issued bonds.

Processing and analysis are carried out as follows:

1. Analysis and calculation of the probability of default using the KMV-Merton method as follows:

Calculates the standard deviation of the growth of assets for each company.

$$
\mathrm{s}=\sqrt{\frac{\sum_{t=1}^{n}\left(r_{t-} \bar{r}\right)^{2}}{n-1}} .
$$

Calculates the value of $\mathrm{d} 1$ formulated as:

$$
\mathrm{d} 1=\frac{\ln _{B}^{V_{\tau}}+\left(r+\frac{1}{2} \sigma^{2}\right) \tau}{\sigma \sqrt{\tau}},
$$

$V_{\tau}=$ is the value of total company assets at time to $\tau$;

$B=$ is the face value;

$r=$ is the risk free interest rate;

$\tau=$ is the time to maturity $(T-t)$;

$\sigma=$ is the standard deviation calculated in the previous stage.

Calculates the distance to default formulated as follows:

$$
D D=d 1-\sigma \sqrt{\tau}
$$

Calculates the probability of default from the Merton model, namely ${ }^{3}$ :

$$
\mathrm{PD}=1-N(D D) .
$$

2. Panel data analysis was carried out with three approaches: the common effect approach, fixed effect approach and random effect approach. The panel data equation model is a combination of cross section data and time series data. This research model is as follows:

$$
\begin{gathered}
Y=\alpha+\beta 1 X 1+\beta 2 X 2+\beta 3 X 3+\beta 4 X 4+e, \\
P D=\alpha+\beta 1 R O E+\beta 2 C R+\beta 3 D E R+\beta 4 T A T+e .
\end{gathered}
$$

The dependent variable in this regression test is the default probability, while the independent variable is ROE, CR, DER, TAT. The formulation of the hypothesis is as follows:

\footnotetext{
${ }^{2}$ URL: http://www.pefindo.com/index.php/pageman/page/ repdesc? $\mathrm{t}=\mathrm{desc} \& \mathrm{id}=4087$ (accessed on 10.01.2020).

${ }^{3}$ URL: http://www.pefindo.com/index.php/pageman/page/ repdesc?t=desc $\& i d=6122($ accessed on 10.01 .2020$)$.
}

$\mathrm{H}_{1}$ : Return On Equity (ROE) has a negative effect on the probability of default (PD).

$\mathrm{H}_{2}$ : Current Ratio (CR) has a negative effect on the probability of default (PD).

$\mathrm{H}_{3}$ : Debt to Equity Ratio (DER) has a positive effect on the probability of default (PD).

$\mathrm{H}_{4}$ : Total Assets Turnover (TAT) has a negative effect on the probability of default (PD).

\section{ANALYSIS AND DISCUSSION RESULTS Panel Data Multiple Regression Test Model selection}

Two tests were carried: the Chow test and the Hausman test. The Chow test is used to choose between the common effect model and the fixed effect model. While the Hausman test is used to choose the random effect model or the fixed effect model. The results of the selected testing of the random effect model are used in the regression model to see the effect of financial ratios on the probability of default.

\section{Classic assumption test}

There is no violation of the assumption of heteroscedasticity and multicollinearity in classical assumptions. The results of heteroscedasticity and multicollinearity tests can be seen in Table 1 .

The output results are provided in Table 1. Based on the heteroscedasticity test using the Glejser test, it appears that the value of the Prob. Chi-Square is 0.0922 greater than $\alpha 0.05$. Thus, it can be concluded that heteroscedasticity did not occur in the data.

The multicollinearity test results can be seen in Table 2. If the Centered VIF value is $<10$, multicollinearity does not occur. Conversely, if the Centered VIF value is $>10$, multicollinearity occurs. In this study, there was no high multicollinearity due to the Centered VIF of all variables smaller than 10, namely 1.156034, 1.107979, 1.211443 and 1.026463.

\section{Significance test for the probability of default model}

From the analysis of the significance tests - both $t$ test and the statistical $\mathrm{F}$ test - the coefficient of determination test shows that the default probability of the model can be used.

1. Significance test $\mathrm{t}$. Table 3 shows that the probability value is $(0.000)<\alpha(\alpha<0.05)$, so that the decision is sufficient evidence to reject $\mathrm{H}_{0}$, which means that the independent variable affects the dependent variable.

2. Due to the statistical $\mathrm{F}$ test, it can be concluded that $\mathrm{H}_{0}$ is rejected, there is at least one independent variable that affects the dependent variable.

3. The determination coefficient test shows that ROE, CR, DER and TAT influence $67.3687 \%$ of the default prob- 


\section{Heteroscedasticity Test}

\begin{tabular}{|l|c|c|c|}
\hline \multicolumn{3}{|c|}{ Heteroscedasticity Test: Glejser } & \\
\hline F-statistic & 2.101687 & Prob. F(4,59) & 0.0919 \\
\hline Obs*R-squared & 7.981868 & Prob. Chi-Square(4) & 0.0922 \\
\hline
\end{tabular}

Source: research data processed.

Table 2

\section{Multicollinearity Test}

\begin{tabular}{|l|c|c|c|}
\hline \multirow{2}{*}{ Variable } & Coefficient & Uncentered & Centered \\
\cline { 2 - 4 } & Variance & VIF & NA \\
\hline C & 1.694935 & 19.04133 & 1.156034 \\
\hline ROE & 0.001213 & 4.097783 & 1.107979 \\
\hline CR & $2.06 \mathrm{E}-05$ & 7.714285 & 1.211443 \\
\hline DER & $3.21 \mathrm{E}-05$ & 5.474227 & 1.026463 \\
\hline TAT & $3.25 \mathrm{E}-05$ & 2.866493 & \\
\hline
\end{tabular}

Source: research data processed.

ability variables. The remaining $32.6313 \%$ is explained by other variables outside the research model.

According to Table 4, the significance of the regression coefficient test independent variable Return on Equity (ROE) shows a negative regression coefficient of -0.010913 with a significance level of 0.9153 . The level of significance is greater than $\alpha=10 \%$. Therefore, it can be concluded that Return on Equity (ROE) does not affect the default probability. Current Ratio (CR) shows a positive regression coefficient of 0.012840 with a significant level of 0.3324; if a significance level is greater than $\alpha$ $=10 \%$, it can be concluded that the Current Ratio (CR) does not affect the occurrence of the default probability. Debt to Equity Ratio (DER) shows a positive regression coefficient of 0.046588 with a significance level of 0.0704 . With a significance level smaller than $\alpha=10 \%$, it can be concluded that Debt to Equity Ratio (DER) has a positive effect on the default probability. Total Assets Turnover (TAT) shows a negative regression coefficient of -0.160879 with a significance level of 0.0543 . The significance level is smaller than $\alpha=10 \%$, so it can be concluded that the Activity Ratio (TAT) has a negative effect on the probability of default.

\section{DISCUSSION}

The results of this study indicate that ROE has no effect on the probability of default. This means that the high or low value of Return on Equity (ROE) does not affect the company's ability to pay its obligations. The results of this study do not correspond to the proposed hypothesis that ROE negatively affects the default prob- ability. If ROE is low, the company lacks the ability to use equity to generate profits and further complicates the company's finances in internal funding sources for investment.

The signaling theory states how the company should give signals to users of financial statements. The information in the form of the provision of published financial statements and bond ratings is expected to be a signal of the company's financial condition and illustrates the possibilities that occur related to the profits owned (Jogiyanto, 2013) [29]. The signaling theory suggests that the management can provide signals in the form of information about the quality or condition of bonds, whether bonds have the potential to default or not. The results of this study show that ROE has no significant effect on the possibility of default, so the signaling theory cannot help investors or creditors to learn about the condition of the company from the given signal. The results of this study are in line with the research by Konstituanto (2012), Agus et al (2014), Almilia and Kristijadi (2003), Mulyaningrum (2008) [9, 12, $19,20]$. However, this study contradicts the research by Saleh and Sudiyatno (2013), Benos and Papanastasopoulos (2005), Widarjo and Setyawan (2009) [11, 17, 18].

The results showed that CR did not significantly influence the probability of default, so the high and low CR values did not affect the probability of default. This is because the current ratio is a measure of liquidity for the short term while the probability of default is a prediction of the term long. The results of this study do not correspond to the hypothesis that CR has a negative effect on the probability of default. This study contrasts with the 
research conducted by Fernandes (2005), Konstituanto (2012), Almilia and Kristijadi (2003), Pranowo et al (2010) $[5,9,19,21]$, while the results of this study are in line with the results of the research conducted by Saleh and Sudiyatno (2013) and Widarjo and Setyawan (2009) [11, 18]. The number of current assets owned by non-financial sector companies taken as a sample is greater than the amount of current liabilities, so that it will be sufficient to cover the company's current liabilities. The more assets the company owns, the company can invest in both current assets and fixed assets, the more market share will be achieved, which will then affect the company's profitability. The signaling theory states how companies should give signals to users of financial statements. The information in the form of the provision of published financial statements and bond ratings is expected to be able to signal the company's financial condition and illustrate the possibility of liquidity. The signaling theory suggests that the management can provide signals in the form of information about the quality or condition of bonds, whether bonds have the potential to default or not (Jogiyanto, 2013) [29]. The results of this study show that CR has no significant effect on the possibility of default, so the signaling theory cannot help investors or creditors to learn about the condition of the company from the given signal.

The results showed that DER had a positive effect on $6.5928 \%$ of the default probability. This means that the higher the DER is, the higher the probability of default is. The results of this study are in line with Jiming and Weiwei (2011) [22] who state that the debt to equity ratio can be used to predict the probability of bankruptcy of a company. However, this study does not support the results of the study by Widarjo and Setyawan (2009) [18] stating that the debt to equity ratio does not affect the probability of company bankruptcy. This ratio illustrates that the greater the ratio is, the greater the amount of company assets financed by debt is, so that the probability of default will also be higher. The high ratio shows that the company uses high financial leverage and the risk of the company will also be high (Hanafi and Halim, 2009) [28]. The results of this study show that DER has a positive and significant effect on the probability of default, according to the signaling theory, which can help investors or creditors to learn about the company's condition from the signals given. Spence (1973) argues that by giving a signal, the sender (owner of information) tries to provide relevant pieces of information that can be utilized by the recipient.

The results show that TAT has a negative and significant effect of $-2.6038 \%$ on the default probability. This means that if the TAT value is high then the default probability value will be lower. The results of this study
Table 3

Summary of Significance Tests for the Probability of Default Model

\begin{tabular}{|l|c|}
\hline \multicolumn{1}{|c|}{ Statistic Criteria } & Value \\
\hline Probability & 0.000000 \\
\hline Prob. (F-statistic) & 0.000002 \\
\hline R Squared & 0.673687 \\
\hline
\end{tabular}

Source: research data processed.

\section{$t$ Test}

Table 4

\begin{tabular}{|l|c|c|}
\hline \multicolumn{1}{|c|}{ Variable } & Coefficient & Prob. \\
\hline ROE & -0.010913 & 0.9153 \\
\hline CR & 0.012840 & 0.3324 \\
\hline DER & 0.046588 & 0.0704 \\
\hline TAT & -0.160879 & 0.0543 \\
\hline
\end{tabular}

Source: research data processed.

support the proposed hypothesis that TAT has a negative effect on the probability of default. This study is in line with the research conducted by Konstituanto (2012), Jiming and Weiwei $(2011)[9,22]$ which state that the ratio of activity affects the probability of default. A high TAT indicates a more efficient use of assets by the company in generating sales and is expected to bring greater profit to the company. The better the financial performance achieved by the company is, the less the probability of default is. TAT has a negative and significant effect on the probability of default, so the signaling theory can help investors or creditors to learn about the condition of the company from the signals given.

\section{CONCLUSION}

The results of the analysis and discussion of the study indicate the following conclusions of the study:

1. Return on Equity (ROE) has no effect on the probability of default.

2. Current Ratio (CR) has no effect on the probability of default.

3. Debt to Equity Ratio (DER) has a positive effect on the probability of default.

4. Total Assets Turnover (TAT) has a negative effect on the probability of default.

\section{SUGGESTION}

The authors' suggestions for the development of future research:

1. It is necessary to compare models, for example, using the Z-Scoring method, if there is a difference be- 
tween the influence of various financial ratios on the probability of default.

2. Increase in the number of research objects and a longer research period.

3. The next researcher can add other variables to the forecast of the probability of default, both financial ratios and non-financial ratios.

\section{RESEARCH LIMITATIONS}

1. The observation period used in this study was four years from 2013 to 2016.

2. The variables in this study are still limited (only ROE, CR, DER and TAT variables were used). Therefore, if this study is used as a reference for future research, other variables need to be added to get optimal results.

\section{REFERENCES}

1. Merton R.C. On the pricing of corporate debt: The risk structure of interest rates. The Journal of Finance. 1974;29(2):449-470. DOI: 10.2307/2978814

2. Crosbie P., Bohn J. Modeling default risk. New York: Moody’s KMV Co.; 2003. 31 p. URL: https://www. moodysanalytics.com/-/media/whitepaper/before-2011/12-18-03-modeling-default-risk.pdf

3. Rudiyanto. Know how bond works 2. Bond Risk Analysis. 2012.

4. Hadad M.D., Wimboh S., Dwityapoetra S.B., Ita R. Probability of corporate default using the Merton model. Reseach Paper. Bank of Indonesia. 2004.

5. Fernandes J. Corporate credit risk modeling: Quantitative rating system and probability of default estimation. SSRN Electronic Journal. 2005. DOI: 10.2139/ssrn.722941

6. Manurung A.H. Company default probability. Journal of Research Finance. 2007.

7. Petru P.T. et al. Empirical study of the probability of default in case of Romanian companies listed on Stock Exchange. Annals of the University of Oradea: Economic Science. 2011;1(1):515-523.

8. Asdriargo A., Maruddani D.A., Hoyyi A. Credit risk measurement of bond prices using the KMV-Merton structural model approach. Journal Gaussian. 2012;1(1):11-20.

9. Konstituanto A., Sanim B., Manurung A.H., Hakim D.B. Bank default probability: Merton model. Jurnal Manajemen. 2011;15(3):293-307. (In Indones.).

10. Muharam H. Credit risk model: Approaches and factors that influence it. Seminar Nasional. 2012.

11. Saleh A., Sudiyatno B. The effect of financial ratios to predict the probability of bankruptcy in manufacturing companies listed on the Indonesia Stock Exchange. Dinamika Akuntansi Keuangan dan Perbankan. 2013;2(1). (In Indones.).

12. Agus S., Irwanto A.K., Maulana T.N.A. Analysis of the effect of financial ratios on the probability of bankruptcy of four banks in the LQ 45 group on the Indonesia stock exchange. Widyariset. 2014;17(1):163-174. (In Indones.). DOI: 10.14203/widyariset.17.1.2014.163-174

13. Ayomi S., Hermanto B. Systemic risk and financial linkages measurement in the Indonesian banking. Buletin Ekonomi Moneter dan Perbankan = Bulletin of Monetary Economics and Banking. 2014;16(2):103-125. (In Indones.). DOI: 10.21098/bemp.v16i2.24

14. Pribadi F., Susanto S. Merton model as predictor of failure probability of public banks in Indonesia. Journal of Economics, Business, and Accountancy Ventura. 2014;17(3):393-404. DOI: 10.14414/jebav.v17i3.361

15. Wendy. The credit risk assessment and failure model of the 1974 Merton model: A conceptual study. Dinamika Akuntansi, Keuangan dan Perbankan. 2015;4(2). (In Indones.)

16. Wibowo B. Method of bank probability bankruptcy measurement and analysis of its relationship with diversification of revenue sources: The case of Indonesian banking. Jurnal Manajemen, Strategi Bisnis dan Kewirausahaan. 2017;11(1):52-66. (In Indones.). DOI: 10.24843/MATRIK: JMBK.2017.V11.i01.p05

17. Benos A., Papanastasopoulos G. Extending the Merton model: A hybrid approach to assessing credit quality. Mathematical and Computer Modelling. 2005;46(1-2):47-68. DOI: 10.1016/j.mcm.2006.12.012

18. Widarjo W., Setiawan D. The effect of financial ratios on financial distress conditions in automotive companies. Jurnal Bisnis dan Akuntans. 2009;11(2):107-119. (In Indones.). DOI: 10.34208/jba.v11i2.174

19. Almilia L. S., Kristijadi K. Financial ratio analysis to predict the financial distres conditions of manufacturing companies listed on the Jakarta Stock Exchange. Jurnal Akuntansi dan Auditing Indonesia. 2003;7(2):183-210. (In Indones.).

20. Mulyaningrum P. Effect of financial ratios on bankruptcy in Indonesia Doctoral dissertation. Program Pascasarjana Universitas Diponegoro. 2008.

21. Pranowo K. et al. Determinant of corporate financial distress in emerging market economy: Empirical evidence from the Indonesian Stock Exchange 2004-2008. International Research Journal of Finance and Economics. 2010;(52):81-90. URL: http://achsani.blog.mb.ipb.ac.id/files/2010/11/irjfe_52_08.pdf 
22. Li J., Du W. An empirical study on the corporate financial dstress prediction based on logistic model evidence from China's manufacturing industry. International Journal of Digital Content Technology and its Applications. 2011;5(6):368-379. URL: http://www.globalcis.org/jdcta/ppl/44_\%20JDCTA_June-48.pdf

23. Brigham E., Houston J.F. Fundamentals of financial management. Transl. from Eng. Jakarta: Four Salemba; 2001. (In Indones.).

24. Spence M. Job market signaling. The Quarterly Journal of Economics. 1973;87(3):355-374. URL: https://msu. edu/ conlinmi/teaching/EC 860/signallingscreening/SpenceQJE 1973.pdf

25. Sartono A. Financial management theory and application. $4^{\text {th }}$ ed. Transl. from Eng. Yogyakarta: BPFE; 2001. (In Indones.).

26. Kasmir. Analysis of financial reports. Jakarta: Rajawali Pers; 2009. (In Indones.).

27. Lukman, Syamsuddin. Corporate financial management. Jakarta: PT Raja Grafindo; 2004. (In Indones.).

28. Hanafi M.M., dan Halim A. Financial statement analysis. Yogyakarta: UPP STIM YKPN; 2009. (In Indones.).

29. Hartono J. Portfolio theory and investment analysis. $8^{\text {th }}$ ed. Yogyakarta: BPFE; 2013. (In Indones.).

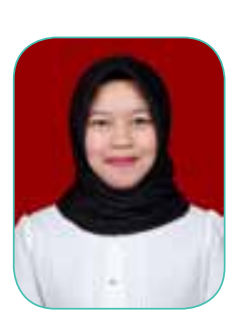

\section{ABOUT THE AUTHORS}

Dessy Malasari - Graduate student, Faculty of Economics, Sriwijaya University, Palembang, Indonesia

dessymal@gmail.com

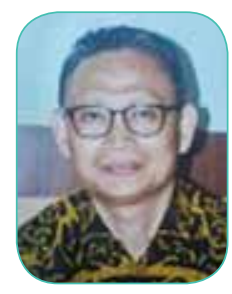

Mohamad Adam - Professor, Faculty of Economics, Sriwijaya University, Palembang, Indonesia mr_adam2406@yahoo.com

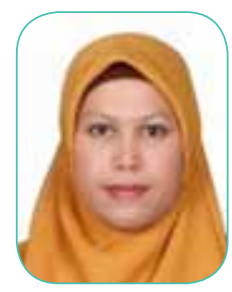

Yuliani - Doctor, Faculty of Economics, Sriwijaya University, Palembang, Indonesia yulianaisyapril@gmail.com

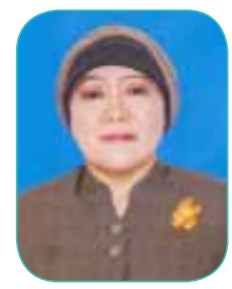

Agustina Hanafi - Doctor, Faculty of Economics, Sriwijaya University, Palembang, Indonesia tinahanafi@ymail.com

\section{Authors' declared contribution:}

Dessy Malasari - The oretical part, methodology, research data collection, analysis of data processing of the results. Mohamad Adam - Modeling in analysis and conclusion of the research results.

Yuliani - Discussion of the research results and the general conclusions of the research results. Agustina Hanafi - Discussion of the research results.

The article was submitted on 28.11.2019; revised on 11.12.2019 and accepted for publication on 20.12.2019.

The authors read and approved the final version of the manuscript.

Статья поступила в редакцию 28.11.2019; после рецензирования 11.12.2019; принята к публикации 20.12.2019. Авторы прочитали и одобрили окончательный вариант рукописи. 